\title{
Örgütsel Çatışma Aracı Olarak Pol-Der Gazetesi
}

\section{Savaș Şimşek}

Elmadağ Polis Meslek Eğitim Merkezi Müdürlüğü

ssim1971@gmail.com

Öz

Türkiye'de 1961 anayasası ile tüm çalıșanlara sağlanan örgütlenme özgürlüğü sonucunda özellikle fordist sistemin 1975 yılından sonra çökmeye bașlaması ile birlikte, örgütlü ișçi sınıfının olduğu kadar örgütlü devlet memurlarının da kendilerini yönetenlerle çatıșma yașadıkları bilinmektedir. Bu durum, yoğun disiplin altında çalıșan polis örgütü personelinin de aynı dönemde kendilerini yönetenlerle çatıșma yașayıp yașamadığı, yașadı ise nasıl bir metot kullanıldığı ve sonucunda nelerin olduğu sorularının cevaplanmasını gerekli kılmaktadır. Bu çalıșmanın amacı, 1980 öncesi polis yönetim ve yöneticilerinin, polis örgütlenmesine olumlu bir yaklașım benimsemediği varsayımından hareket ederek söz konusu sorulara yanıt aramaktır. Araștırmanın örneklemi olarak Pol-Der gazetesi seçilmiștir. Zira 1975 yılında kurulan Pol-Der (Polis Derneği) yönetici ve üyeleri, mesleki çıkarlarını korumak amacıyla Pol-Der Gazetesi'ni, kendilerini yönetenlere karșı bir çatıșma aracı olarak kullanmıșlardır. Araștırmada söz konusu çatıșma, Pol-Der Gazetesi'nin incelenmesi yoluyla ortaya konulmaya çalıșllacaktır.

Anahtar Kelimeler: Örgütsel çatıșma, örgütsel iletișim, örgütsel direnç, Polis Derneği, Pol-Der gazetesi

Makale geliș tarihi: 06.10.2015 - Makale kabul tarihi: 08.11.2015

http://ilefdergisi.org/2015/2/2/

ilef dergisi · (c) $2015 \cdot 2(2) \cdot$ sonbahar/outumn: 131-154 


\section{Pol-Der Newspaper as an Instrument of Organizational Conflict}

\section{Savaș Şimşek}

The Directorate of Elmadağ Police Training Centre

ssim1971@gmail.com

\section{Abstract}

After the freedom of assosiciation given to all workers by the constitution of 1961 in Turkey, especially with the collapse of fordist system after 1975, it is known that assosiciated state officials as well as assosiciated workers had conflict with the people who govern them. This situation requires the answer of the questions, such as whether police staff who works under high discipline had any conflict with the people who govern them, if so, what kind of method they used and what happened at the end of that conflict. The aim of this research is to try to find out answers of those mentioned questions with the hypothesis that the police management and managers of pre-1980 did not have positive approach to police assosicitionism. Pol-Der newspaper was selected as an sample of this research. This is because managers and members of Pol-Der (Police Assossiciation), which was established in 1975, used Pol-Der newspaper as an instrument of conflict against people who govern them to cover their vocational interests. In the study, the aforementioned conflict will be stated through the analysis of the Pol-Der newspaper.

Keywords: Organizational conflict, organizational communication, organizational resistance, Police Assosiciation, Pol-Der newspaper. 
İnsanların sosyal bir varlık olarak nitelenmesinin ana nedeni onların başta hemcinsleri olmak üzere doğadaki diğer varlıklarla etkileşim halinde olmalarıdır. Bu etkileşim kendi içinde bazı unsurları da barındırmaktadır. Özellikle ihtiyaçlar, değerler ve güdüler ile bunlara uyarlanmış iletişim kanalları insanların diğerleri ile olan ilişkilerinin ana temellerini oluşturmaktadır. İnsanların birbirleri ile iletişimlerinde kimi zaman sözlü kanallar hâkim iken, kimi zaman hareket, mimik veya tavırları barındıran sözsüz kanalların baskın olduğu görülmektedir. Fakat burada konumuz; ihtiyaçlar, güdüler, değerler veya iletişim kanallarının niteliklerinden çok özellikle genel anlamda örgütlerde insanların amaçlarına ulaşamadıkları zaman takındıkları tavır ve diğer insanlarla girdikleri çatışma durumu ile bunları yansıtma yollarıdır. Özellikle belirli amaçların gerçekleşmesi için oluşturulan örgütlerde ast ve üst konumda olanlar arasındaki farklı örgütsel çıkarların karşı karşıya gelmesi, çatışmayı her an olabilir kılmaktadır. Polisler de birer çalışan olarak değerlendirildiğinde, onların da üst yönetimleri ile belirli çıarlar nedeniyle çatışmaya girmeleri muhtemeldir. Türkiye'de bu tür bir çatışmaya örnek olarak polislerin 1980'den önce kurdukları Polis Derneği (Pol-Der) ve Polis Birliği Derneği (Pol-Bir) isimli meslek örgütlerinin, o dönemin polis ve siyasi yöneticileriyle yaşadıkları sorunlar verilebilir. Pol-Der'in kurulması ile başlayan 
süreçte polis dernekleri -özellikle Pol-Der- bir disiplinin hâkim olduğu polis örgütü içinde ayrı bir örgütlenmeyi kabul etmeyen iktidarlarla, kapatıldıkları tarihlere kadar sürekli bir çatışma halinde olmuşlardır. Pol-Der mesleki sorunları ve mesleğin halk tarafından algısını düzeltmek için çabalarken, o dönemin polis ve siyasi yöneticileri kendi emirlerinde olan bir örgütün mensuplarının kendilerinden ayrı düşünce ve önerilerle öne çıkmalarına karşı durmak ve 1980 öncesi kaos ortamında alınacak güvenlik temelli tedbirlerde özellikle polisi baş aktör olarak kullanmak istemişlerdir. Bu çatışma grev veya boykot gibi bilinenin aksine yazılı ortamda sürmüş, Pol-Der Gazetesi ise bu çatışmada temel bir araç görevi görmüştür. Bu nedenle çalışmanın temel konusunu 1975 yılında kurulan Polis Derneği'nin (Pol-Der) yayın organı olan Pol-Der Gazetesi'nin, derneğin polis örgütünün üst yönetimi ile ilişkisinde nasıl bir çatışma mekanizması olarak kullanıldığı oluşturmaktadır. Polis Birliği Derneği (Pol-Bir), Pol-Der'den üç yıl sonra, Pol-Der'deki yönetsel ve fikirsel uygulamaları kendi dünya görüşlerine uygun bulmayan ve Pol-Der yönetiminde de yer alamayan polis personeli tarafından, Pol-Der başta olmak üzere "sol" düşünceyi benimseyen tüm siyasi oluşumlara karşı olmak amacıyla kurulmuştur (Şimşek 2015, s.295-296). Her ne kadar Pol-Bir'in de kendi yayın organı bulunsa da, Pol-Der Gazetesi kadar adından söz ettirememiştir. Bunun nedenleri arasında Pol-Der'in daha önce kurulmuş olması, toplumun faklı birçok kesimince kabul görmesi (Öner 2003, s.82-84), daha fazla üyeye sahip olması (Cumhuriyet 1978, s.1; Öner 2003, s.94), coğrafi olarak daha fazla alanda örgütlenmiş olması ve Pol-Bir'in bir yıl gibi kısa bir süre faaliyet göstermesi sayılabilir. Bu nedenle çalışmanın odağını Pol-Der Gazetesi teşkil etmektedir. Çalışmanın temel konusu açıklanırken öncelikle çatışma kavramının tanımsal analizinden başlanacaktır. Bu tanımsal analiz çerçevesinde çatışma bir süreç olarak değerlendirilerek, çatışma unsurları üzerinde durulacaktır. Çatışmanın en önemli kanallarından biri olan iletişim üzerinde de durulacak olan çalışmada ana tema olan Polis Derneği'nin (Pol-Der) kuruluşuna ve PolDer Gazetesi'nin tarihçesine kısaca değinilerek Pol-Der'in eski üyelerinden elde edilen Pol-Der Gazetesi nüshalarında polislerin, örgüt üst yönetimi ile girdikleri çatışmalarda kullandıkları dikkat çekici yazılara yer verilecektir.

\section{Örgütsel çatıșmanın kavramsal analizi}

Temel olarak her örgütsel yapının organik tarafı yöneten ve yönetilen ayrımı üzerine kuruludur. Yöneten ve yönetilen arasındaki ilişkilerin her zaman belirli bir ahenk içerisinde sürmesi beklenirken sonuç beklenildiği gibi de olmayabilmektedir. Her iki tarafta da insan unsuru göz önünde bulundurulduğunda, yaşamlarına dair çıkarların da örgütsel ilişkilerde baskın olduğundan 
bahsetmek mümkündür. Örgütsel anlamda çatışma, birbirinden bağımsız iki insanın birbirlerininkine zıt amaç, hedef ve değerlere sahip olması ile birbirlerini kendi amaçlarını gerçekleştirmede potansiyel müdahil olarak görmeleridir (Putnam ve Poole 1987, s.552). Yönetenler genel anlamda en fazla faydayı kendileri için düşünürken, yönetilenler daha az güç sarf ederek daha fazla para kazanmayı, çalışma şartlarının mevcut durumdan daha kötüye gitmemesini ve çalışma sonunda elde edecekleri manevi menfaati sağlamak için ellerinden geleni yapmayı istemektedirler. Her iki tarafın bu tür davranış geliştirmesi örgüt içerisinde çatışmaya zemin hazırlamaktadır. Dolayısıyla çatışma genel olarak iki varlık arasındaki olumsuz bir durumu ifade etmektedir denebilir. $\mathrm{Bu}$ olumsuzluk ise bir uyuşmazlık durumudur. Bu uyuşmazlığın temelinde de örgüt içerisindeki bireylerin/tarafların sahip oldukları çıkarların farklılığı bulunmaktadır (Martin ve Fellenz 2010, s.300). Eğer çatışma belirli bir ilişki durumunun sonucunda meydana geliyor ise burada bir süreçten bahsetmek gerekmektedir. Bu durumda bir süreç olarak çatışma, bir tarafın, diğer tarafın kendi çıkarlarına karşı geldiğini veya çıkarlarının onun tarafından olumsuz etkilendiğini algılaması olarak tanımlanabilir (Kinicki 2003, s.222). Örgüt içerisinde bir süreç olarak meydana gelen çatışma, tarafların birbirinden haberdar olmaları, iletişim, direnç gibi unsurları içinde barındıran ve bunların sırasıyla meydana gelmesi sonucunda oluşan bir olgudur. Bu nedenle onu meydana getiren unsurların neler olduğu üzerinde de durulmalıdır.

\section{Haberdar olmak}

İnsanoğlu normal hayatında kendisi haricinde konumu olan diğer varlıklar ile birlikte birçok alanı paylaşmaktadır. Onun iletişim halinde olduğu baş aktörler ise kendisi gibi olan diğer insanlardır. İnsanlar birbirleri ile iletişime girmeden önce birbirlerinden haberdar olmaktadırlar. Haberdar olmak kendi içerisinde kiminle, hangi amaç için iletişim kurulabileceğini idrak etmeyi barındırmaktadır. Örnek olarak; örgüt içerisindeki bir çalışanın, kendi özlük bilgileri ile ilgili olarak başvurması gereken yerin İnsan Kaynakları Şubesinin Özlük Hakları bürosunda çalışanlar olduğunu bilerek hakkında işlem yapılabilmesi için belirtilen kişilere müracaat etmesi gerektiğinden haberdar olması verilebilir. Haberdar olma durumu bu anlamda girilecek iletişimin niteliğini de belirlemektedir. Örgüt üst yönetimlerinin alt kademelere yönelik iletişimi emredici iken, örgüt alt kademelerinin yukarıya doğru iletişimi arz edici ve daha saygı içeriklidir.

Haberdar olmak, çalışanlara, örgüt içinde kimlerin ne yetkisi olduğunu da belirtmektedir. Bu tür bir durumu yetkilerin yanı sıra sorunların kay- 
naklarının nereler olduğunu anlamak şeklinde de genişletmek mümkündür. Örneğin, ürün veya hizmet üretiminde meydana gelen kalite düşüklüğünde asıl sorunun örgütün hangi kademesi olabileceğini anlamak ürün olarak karşılaşılan sonucun değerlendirilmesinden anlaşılabilmektedir. Bu kapsamda örgütsel ve mesleki sorunlara çözüm bulunacak merkezlerin de hangi kademeler olabileceği haberdar olma açısından da düşünülebilir. Diğer taraftan sorunların merkezi olarak belirlenen kademelerin, çözüme ulaşılamaması neticesinde çatışılacak kademeler olarak ortaya çıkması yine haberdar olma açısından değerlendirilmelidir.

\section{Iletișim}

İletişim, tek başına tanımlandığında kendi içinde ayrı bir süreçtir. Fakat çatışma konusuyla ele alındığında, belirli bir sürecin parçası haline gelmektedir. İletişimi çatışma ile ilgili olarak; etkileşim-iletişim-çatışma şeklindeki sürecin odak noktasında konumlandırmak mümkündür (Putnam ve Poole 1987, s.552). Fakat iletişimin kendisi de başlı başına bir süreçtir. İletişimin unsurları ise mesaj, mesajı gönderen ve alan ile bu ikisi arasındaki mesaj trafiğinin gitgelleridir (Reece ve Brandt 1999, s.35). Konumuz gereği burada mesajı gönderen ve alanın yanı sıra mesajın niteliği ile mesajın gönderilme nedenleri üzerinde durulmalıdır. Zira, bahsi geçen unsurlar iletişim sürecinde çatışmay1 yaratan önemli olgulardır. İnsanlar iletişimlerine deneyimlerini, tavırlarını, değerlerini, çıkarlarını, güdülerini, sanrılarını ve beklentilerini katmaktadırlar (Reber ve Terry 1975, s.163). Bunlara ek olarak da insanların ihtiyaçları belirtilebilir (Thayer 1961, s.45). İnsan ihtiyaçları yukarıda belirtilen unsurlar ile bezenerek iletişim gerçekleşmekte, insanların içinde bulundukları durum karşı tarafça anlaşılmadığında veya anlaşılmak istenmediğinde ise çatışma gerçekleşmektedir. Dolayısıyla iletişimin aslında insanların genel olarak bireysel-sosyal ihtiyaçlarını karşılamak, örgütsel olarak da örgütsel amaçları gerçekleştirmek için başvurdukları bir yol olduğu söylenebilir. İnsan ihtiyaçlarının temeli ise yaşamda karşılaştıkları sorunların üstesinden gelme isteğidir. İnsanlar dâhil oldukları iletişim sonucunda kimi zaman olumlu geri bildirimler aldıkları gibi kimi zaman da kendi düşüncelerine, çıkarlarına ve hayat tarzlarına aykırı bir takım geri bildirimler almaktadırlar. Diğer bir ifade ile iletişim insanların sorunlarını hallettiği gibi sorun da yaratabilmektedir (Richmond vd. 2005, s.18).

Yukarıda bahsi geçen durumu örgütlere de uyarlamak mümkündür. Yönetenler ve yönetilenler açısından bakıldığında her iki grubun da iletişimlerinde kendilerine özgü kişisel ve düşünsel özelliklerinin yanı sıra bireysel ve 
grupsal ihtiyaçların bulunduğunu belirtmek yanlış olmayacaktır. Bu farklılık her iki grup arasında kendine has istek ve ihtiyaçları öncelikli olarak yerine getirmek ve sonuçta çatışmayı yaratmak için zemin hazırlamaktadır. O halde Follett'ın da belirttiği gibi çatışma farklılıktır ve kaçınılmazdır (aktaran Metcalf ve Urwick, 2003, s.29). Örgütsel iletişimde yönetenlerden yönetilenlere (aşağı), yönetilenlerden de yönetenlere (yukarı) doğru bir iletişim bulunmaktadır. Aşağıya doğru iletişim genellikle düzenleyici ve yönetsel iken, yukarıya doğru iletişim ise bilgi verici, ikna edici, katılıma dönük ve sosyalizasyona yöneliktir (Richmond vd. 2005, s.10-12). İster aşağıya ister yukarıya doğru olsun yöneten ve yönetilenler arasındaki iletişim eksikliği (Eisenberg ve Goodall 2004, s.167) ile statü farkı, yanlış anlama, yanlış bilgilendirme ve anlaşmazlık gibi olguları içinde barındıran iletişim engelleri (Bormann vd. 1969, s.145) örgütsel çatışmanın temelidir.

\section{Direnç}

Direnç, özellikle insanlar veya gruplar arası güç ilişkilerinde tarafların birbirlerinin faaliyetlerine dönük karşıtlıklarını içeren reaktif bir süreçtir (Jermier vd. 1997, s.9). Örgütsel açıdan yapılan bir tanıma göre ise direnç, yönetim tarafından çalışanlara yönelik isteklerinin şiddetini azaltmak veya yönetime karşı çalışanların taleplerini artırmak isteyen kişi ya da grupların eğilimidir (Hodson 1995, s.80). Direnci, tarafların birbirlerinden haberdar olmaları ve iletişimleri neticesinde çatışmadan önce meydana gelen olumsuz bir tavır olarak da tanımlamak mümkündür. Direnç bir tepkidir. O halde bu tepkiyi ortaya çıkaran nedenler ve bu tepkinin çeşitleri üzerinde durulmalıdır.

Çatışmanın yaratılmasında direncin önemli bir katkısı bulunmaktadır. Direncin meydana gelmesinde ise gerçekleşen iletişimin niteliğinin önemi büyüktür. Gibbs, direncin meydana gelmesinde iletişimdeki önemli noktaları açıklamaya çalışmıştır (1943, s.45-48). Ona göre konuşmacının tavrı, ses tonu ve konuşma içeriği dinleyiciyi değerlendirme veya yargılama halinde ise dinleyici de bu durum karşısında direnç gösterir. Ayrıca dinleyiciyi kontrol etmek amacıyla kullanılan konuşma dinleyicide direnç ortaya çıkarmaktadır. Konuşmacının gizli gündeminin olduğunu anlayan dinleyiciler de konuşmacıya karşı direnç göstermektedirler. Tarafsızlık içeren konuşmalarda kendi durumu ile ilgilenilmediğini anlayan dinleyiciler de yine direnç gösterebilmektedirler. Ayrıca birine karşı yoğun, güçlü ve daha değerli hisler ile konuşulduğunda, bu durum dinleyicide savunma hissi uyandırır. Her şeyin bilindiğinin ima edilmesi de dinleyen kişinin savunmaya geçmesine neden olmaktadır. Gibbs, her ne kadar burada direnci meydana getiren yüz yüze bir 
iletişimin niteliğinden bahsetmekte ise de bu durumu diğer iletişim kanallarına uyarlamak mümkündür.

Direnç, dört farklı şekilde gösterilmektedir. Bunlar sırasıyla reddetme, ses yükseltme, kaçma ve yaratıcılıktır (Fleming ve Spicer 2007, s.41-50). Luthans, kaçma eylemini “sakınma” olarak nitelemektedir (1989, s.290). Bunun yanında özellikle örgütlerde çalışanların üst yönetime huzursuzluk ve direncini bildirirken, yüz yüze konuşup yönetime katılma, kamuoyu oluşturma, medyayı kullanma veya değişik örgütler kurmak (sendika, dernek vb.) gibi yolları kullanmaktadırlar (Fleming ve Spicer 2007, s.41-50). Konumuz gereği örgütlerde çalışanların kamuoyu oluşturmaları, medyayı kullanmaları ve değişik birliktelikler oluşturmaları önem arz etmektedir. Çalışanlar meslekleri ile ilgili konularda kamuoyu oluşturmak için öncelikle birliktelikler oluşturmakta daha sonradan da oluşturulan sinerji ile medyayı kullanarak diğer insanların da karşılaştıkları örgütsel sorunlardan haberdar olmalarını sağlamaktadırlar. Gelişen teknoloji insanların birbirleriyle her an haberleşebilme imkânı sağlamaktadır. Özellikle son dönemde internet yoluyla oluşturulan birliktelikler ve sonuçta meydana gelen sosyal medya da insanların kısa sürede birbirlerinden haberdar olmalarına yardımcı olmaktadır.

Örgütlerde çalışanların oluşturduğu yayın organlarını, “örgütün yayınlattığı" ve "çalışanların yayınladıkları" yayın organları olmak üzere iki şekilde ele almak mümkündür (Heusser 1958, s.133). Bunlardan birincisi örgütün üst yönetimi tarafından maddi destek sağlanarak çıkarılan yayın organıdır ki, bu tür yayın organlarında ele alınan konular üst yönetim ile çatışmaya girmekten uzak, genel olarak üst yönetimin belirlediği konulardır. Diğer bir yayın organı ise yine örgüt içinde çalışanlar tarafından fakat çalışanların maddi katkıları ile yayınlanan ve yine örgüt üst yönetimi ile çatışmaya girmeden yayınına devam eden yayın organlarıdır. Belirtilen yayın organları ile birlikte ülke genelindeki medya organlarının yanı sıra çalışanlar tarafından oluşturulan birliktelikler de kendilerine özgü yayın organlarını oluşturmakta ve kamuoyunu bilgilendirmeye çalışmaktadırlar. Bu tür yayın organları örgütlerin üst yönetimlerinden bağımsız olmaları nedeniyle, üyesi bulunulan örgütleri mesleki her konuda eleştirmekte ve mesleki menfaatlerini kamuoyu oluşturarak korumaya çalışmaktadırlar.

Özetle belirtmek gerekirse örgütsel çatışma, yöneten ve yönetilen ekseninde belirli örgütsel ve mesleki menfaatleri kendi içerisinde barındıran ve bu olgular temelinde karşılıklı olarak haberdar olma-iletişim-direnç şeklinde meydana gelen bir süreçtir. Bu süreç Pol-Der yönetimi ve üyelerinin polis 
yönetimi ile karşı karşıya gelmeleri ile çıkan çatışmaya da uyarlanabilir. Her ne kadar ileriki bölümlerde konuya detaylı olarak değinilecek olunsa da burada Pol-Der yönetimi ve üyelerinin çatışma sürecindeki haberdar olma-iletişim-direnç unsurlarını nasıl safha safha katederek sonuçta çatışma noktasına geldiklerine açıklık getirilmelidir. 1961 anayasası ile gelen özgürlükçü yaşam neticesinde ortaya çıkan yönetimden haberdar olma ve kurulan meslek örgütleri yoluyla yönetime katılma, bir kısım meslek mensuplarının kendi mesleki menfaatleri ile ilgili birçok konuyu başta kendi üst yönetimleri olmak üzere siyasilere ulaştırmalarına da olanak sağlamıştı. Polislerin çalışma koşulları çok ağır olmasına karşın bu tür sorunları yöneltebilecekleri bir araçları yoktu. Öner'e göre Pol-Der bu amaçla polis içindeki solcuların kurduğu bir dernekti (2003, s.33). Pol-Der yönetimi mesleki sorunların üstesinden gelecek olanların öncelikle siyasi kadrolar daha sonradan polis üst yönetimi olduğundan haberdard1. Pol-Der kurulmadan önce olduğu gibi kurulduktan sonra da siyasiler ve polis üst yönetimi iletişim kanallarını Pol-Der'in "solcu" bir örgüt olması nedeniyle kapatmışlardır (Öner 2003, s.40-41). Bunun yanı sıra polis örgütünü idare edenler bir disiplin mesleği olarak gördükleri meslek mensuplarına karşı sorun halledici olmaktan çok sorun yaratıcı emirlerle bir karşı duruş sergilemeyi tercih etmişlerdir. Sonuçta Pol-Der yönetimi meslek sorunlarına karşı bu tür umursamazlık gösteren polis yöneticilerine hem ulaşmak hem de kamuoyu oluşturmak amacıyla Pol-Der'in yayın organı olan Pol-Der Gazetesi'ni kullanmışlardır.

\section{Polis Derneği'nin (Pol-Der) kurulușu ve Pol-Der Gazetesinin olușumu}

Pol-Der sadece birkaç polisin bir araya gelerek bir anda oluşturdukları bir örgütten çok mesleki birçok zorluğu içeren çevresel ve tetikleyici faktörleri içinde barındıran şartlar sonrasında oluşan bir meslek örgütüdür (Şimşek 2015, s.287). Çevresel faktörleri ekonomik, siyasal, yasal ve kurumsal faktörler olarak ayırmak mümkündür. Yasal anlamda 1961 anayasası ile memurlara tanınan örgütlenme hakkını belirtmek gerekir (1961 Anayasası Mad. 29). Fakat bu hak Türkiye'de artan kitlesel hareketler ve toplumsal ayrışma gerekçe gösterilmek suretiyle 1971 yılında yapılan yeni bir düzenleme ile sendikalaşmadan dernekleşmeye çevrilmiş, bu yıldan sonra memurlar sadece dernekleşmek suretiyle örgütlenebilmişlerdir. Ekonomik açıdan ise ulusal ve uluslararası ekonomik gelişmelerden bahsedilebilir. 1973 yılındaki Arap-İsrail savaşı neticesinde artan petrol fiyatları, 1974 yılında Türkiye'nin Kıbrıs'a iki kez müdahale etmesi, bunun sonucunda ABD'nin uyguladığı ekonomik 
ambargoyla Türkiye'nin dövize olan ihtiyacının artması (Koç 2010, s.247) ve işçi-işveren arasındaki uyuşmanın simgesi olan fordist düzenin kaybolmaya başlaması (Aslan 2005, s.62) örnek verilebilir. Siyasal nedenler arasında o dönem Türkiye' de kısa aralıklarla meydana gelen hükümet değişiklikleri nedeniyle oluşan siyasi istikrarsızlıklar ve bu durumun yol açtığı toplumsal ayrışma gösterilebilir. Kurumsal olarak söylenebilecek nedenler arasında ise örgüt personelinin içinde bulunduğu görev ve yaşam koşulları gösterilebilir. Buna göre polis personelinin görev yerlerinin sağlıksızlığı, sürekli görevde olmaları, izin aldıklarında maaşlarında belirli bir eksiltmenin yapılması ve buna karşın aldıkları maaşın az olması ile örgüt üst yönetiminin bu duruma ilgisiz kalması polisleri kendi hak ve menfaatlerini savunacak bir meslek örgütü kurmaya itmiştir (Şimşek 2015, s.281-282). Pol-Der, 1970 yılında kurulan ve Polis Derneği olarak bilinen derneğin 17 Mayıs 1975'te yeni bir yönetim tarafından devralınması ile oluşturulmuş bir meslek örgütüdür (Öner 2003, s.34).

Pol-Der kurulduğunda önemli olan coğrafi açıdan yayılmanın sağlıklı bir biçimde gerçekleşmesini ve mümkün olduğunca çok üye kaydedilerek bu üyelerin hak ve menfaatleri ile mesleğin menfaatlerinin korunmasını sağlamaktı. Bu nedenle iki faydalı aşama kaydedildi. Bunlardan birincisi- ki PolDer'in polis örgütü içinde yayılmasına en fazla katkıyı sağlamıştır- hukuki yardımdır. Pol-Der üyelerinin hakları, örgütün kiraladığı iki avukat yardımı ile hukuki açıdan korunmaya çalışılmıştır. Bu açıdan bakıldığında Pol-Der, kimilerine göre sendikal amaçlı bir dernekti (Gülmez 1996, s.50). Diğer bir önemli aşama ise Pol-Der Gazetesi'nin yeniden yayınına başlatılması olmuştur. Aslına bakılacak olursa bu gazetenin "Gerçek Polisin Sesi" adı altında 1970 yılında kurulan Polis Derneğinin yayın organı olarak 1974 yılına kadar yayımlandığını ve yönetim değişikliği nedeniyle yayına bir müddet ara verildiğini, örgütün mali işler sorumlusu Polis Memuru Dinçer Birol'un yazısından anliyoruz:

Derneğimiz Yayın organı olan "Gerçek Polisin Sesi” gazetesinin çeşitli nedenlerle 5 Eylül 1974'ten bu yana yayınlanamayışı Merkez Yönetim Kurulumuzun yapmış olduğu olumlu çalışmaları üyelerimize duyuramamış ve üyelerimizle haberleşme olanağının kalmaması gibi bir durumla karşılaşılması 17.05.1975 günü yapılan 4. Olağan Genel Kurul neticesinde görev verilen yeni Yönetim Kurulunca ele alınmış ve il olarak üyelerimizle Dernek arasındaki haberleşmenin sağlanması yoluna gidilmesi Merkez Yönetim Kurulumuzun hazırlayarak üyelerimize, Siirt, Erzurum, İstanbul Şube Başkanlarımızca, Şubelerimizin bulunmadığı diğer il ve ilçelerde de temsilcilerimiz kanalı ile sunulmuş olan 5. Dönem çalışma planımızda hedef ve çalışmalarımızın neler olduğu ve neler olacağı saptanmış idi. 
Pol-Der olarak hiçbir fikir akımının yanında olmadığımızı, yöneticileri de ne kişisel ne de yönetimlerinden dolayı hedef almadığımızı yapılan tüm çalışmaların meslek mensuplarımızın daha iyi koşullar içerisinde görev yapma olanaklarına kavuşturulması yönünde olduğu ve tüzüğümüzde belirtilen bütün amaçların gerçekleştirilmeye çalışılması bu faaliyetlerin de olumlu sonuçları basın, yayın organları ve bu günden itibaren yayınlanmaya başladığımız gerçek sesimizi duyuracak olan Pol-Der'imizle gözler önüne sergilenecektir.

Teşkilat mensuplarımızın bilinçli olarak derneğimiz etrafında toplanması ve halen çok zayıf olan Pol-Der'in mali gücünün kuvvetlendirilmesi, varılması istenilen hedefleri kısaltacağı ve çalışmalarımızı daha etkin kılacağı inancındayız.

Yeniden yayına başlamakla kıvançlıyız (Birol 1975, s.1).

Yukarıdaki yazıdan derneğin kuruluş amacının sadece mesleki menfaatler olduğu, aslında üst yönetim ile herhangi bir çatışmanın amaç edinilmediği anlaşılmaktadır. Önceleri aylık olarak yayınlanmaya başlayan Pol-Der Gazetesi'nin daha sonraları her ne kadar haftalık olarak da okuyucularına sunulmaya başlandığı belirtilmişse de (Şimşek 2015, s.293). Pol-Der yönetiminin ileri dönemlerde yaşadığı sorunlar nedeniyle iki veya üç ayda bir yayınlandığı da anlaşılmaktadır. Bu nedenle Pol-Der Gazetesi 23 sayıya ulaşarak en son Eylül 1978' de basılmıştır.

Pol-Der Yönetim Kurulu, görevi devraldıkları ilk günlerden itibaren, polis örgütünün üst yönetimi ile sorunlar yaşamaya başlamıştır. Bu sorunlardan birincisi, polis örgütü ve polislerin menfaatlerini, ister örgütsel olsun ister siyasi olsun, yeteri kadar savunmadıklarını düşündükleri Emniyet Genel Müdürlüğü ve İçişleri Bakanlığı yetkililerini aşarak İçişleri Bakanlığı Bütçe görüşmelerinde polisin durumunu ve alması gereken maaş ile ilgili önerilerini belirtir bildirinin Meclis Bütçe Komisyonu üyelerine dağıtılması olmuştur (Şimşek 2015, s.293-294). Bu hareket dönemin İçişleri Bakanı Oğuzhan Asiltürk'ün tepkisini çekmiş ve zaten polis içinde ayrı bir oluşuma tahammülü olmayan üst yönetimi Pol-Der'i kısıtlamak için gerekli önlemler almaya itmiştir. Bu önlemler ise dönemin siyasi iradesinin polis örgütünün başına ve alt kademelerine kendi siyasi düşüncesine uygun insanları istihdam etmesidir. Oysaki Pol-Der ile onun yanında yer alan ve o dönem faaliyet gösteren Uluslararası Polis Derneği (IPA) Türkiye Şubesi ile Polis Enstitüsü mezunlarının kurdukları Polens Derneği'nin karşı olduğu konular, polis örgütünün siyasetten uzak ve tarafsız olması ile polislerin polisler tarafından yönetilmesidir.

....Evet polis değillerdi. Bu nedenle göreve başladıklarında polisi ve hizmeti tanımak, sorunlara vakıf olabilmek için zamana uzun zamana ihtiyaçları vardı. Polis 
olabilecekleri zamana. Bu intibak dönemlerinde polisin sorunlarına yenilerinin eklenmesi bir bakıma doğaldı. Nitekim böyle oluyordu. Ve yaralar büyüyor, zaman boşa geçiyordu. İntibak döneminin uzaması huzursuzlukları artırıyordu. Sonra bir başka göreve atanıorlardı. Senaryo hiç değişmiyordu. Ama böyle gitmezdi, gidemezdi. Bu gidişe dur demek zorunlu olmuştu (Erkan 1974, s.3).

Polis örgütünün üst kademesine dışarıdan sivillerin atanmasına yapılan bu itirazın yanı sıra Pol-Der ve Uluslararası Polis Derneği (IPA) Türkiye Şubesi, İmam Hatip Okulları'nda okuyanların imtihansız olarak polis örgütüne alınmasına da itiraz etmekteydiler. Polis üst yönetimi ile Pol-Der ve diğer iki dernek arasında çıkan bu çatışmanın gerisinde yatan olaylar şu şekilde gelişmiştir: 1974 yılında yayımlanan “Emniyet Teşkilatında Bir Memuriyete İlk Defa Atanacaklar için Zorunlu Yeterlilik ve Yarışma Sınavları Hakkında Yönetmelik"in 10. maddesindeki adayların askerlik durumları ile ilgili 1975 yılında bir değişiklik yapılmıştır. Yapılan değişiklikten önce polis olarak alınacakların askerliklerini "eylemli" olarak ifa etmiş olmaları şartı varken, yapılan yeni düzenleme ile askerlik durumu detaylandırılarak, askerlikle ilgisi bulunmamak, askerlik çağına gelmiş olmamak veya askerlik çağına gelmiş ise askerliğini eylemli olarak ifa etmiş olmak gibi alt maddeler eklenmiştir. Diğer taraftan daha önceki yönetmelikte yaş olarak üst sınır otuz yaşından gün almamış olarak belirtilirken yeni yapılan düzenlemede başvuracaklar yaş yönünden de detaylandırılmış, başvuranların yaşları 18 yaşını bitirmiş ve 30 yaşından gün almamış olarak belirlenmiştir. Bu değişikliğin geçmişinde ise yine siyasi popülizm ve kadrolaşma hareketi görülmektedir. 29 Mayıs 1975 tarihinde yapilan ve İstanbul'un Fethi'nin 522 yıldönümüne denk getirilen MSP Gençlik Kolları tarafından düzenlenen “Fetih Gecesi”nde, askerliklerini yapmamış İmam Hatip mezunlarının polis olma isteklerine olumlu yanıt verilmiştir (Barış 1975, s.1). "Emniyet Teşkilatında Bir Memuriyete İlk Defa Atanacaklar için Zorunlu Yeterlilik ve Yarışma Sınavları Hakkında Yönetmelik" in 10. maddesinde 1975 yılında yapılan değişiklik Pol-Der, Polens ve IPA Türkiye Şubesi başkanları tarafından idari yargıya taşınmış ve sonuçta söz konusu değişiklik Danıştay tarafından iptal edilmiştir. Pol-Der'in diğer polis meslek örgütleri ile gösterdiği kanuni bu dirence konu olan kadrolaşma hareketi hakkında Pol-Der'in o dönem avukatlığını yapan Sami Çapakçur ile Uğur Alacakaptan'ın birlikte Pol-Der Gazetesi'ne verdiği demeç hayli açıklayıcıdır:

Tarihli tarihsiz bir kısmı aynı elden çıkmış, tamamı İmam Hatip Okulu veya İslam Enstitüsü öğrencilerine ait dilekçeler gönderilmiş ve bunların sınava alınmaları istenilmiştir. Bahsekonu dilekçelerin bin beşyüz adedi 29 Mayıs 1975 tarihinde yapılan fetih gecesinden sonra bizzat İçişleri Bakanlığı tarafından Emniyet Genel 
Müdürlüğüne gönderilmiş ve hatta bu dilekçelerin bir kısmında yalnız adı, imzaS1 ve İçişleri bakanlığına ibaresi bulunmaktadır. 9 Haziran 1975 tarihinde verilen bin kadar dilekçe ise Bakanlık Evrak Bürosundan geçirilmeden alt köşelerinde müftülük imza ve mühürünü havi bir şekilde İçişleri Bakanlığınca gereği için Emniyet Genel Müdürlüğüne havale edilmiştir. Yönetmelikteki değişikliklerin sırf bu dilekçe sahiplerini emniyet kadrolarına alabilmek için yapıldığı aşikârdır (Pol-Der 1975a, s.1) ${ }^{1}$.

Kadrolaşma hareketinin önüne hukuk yoluyla karşı çıkan Pol-Der yönetimi ve üyeleri bu olaydan sonra iktidarın öncelikli hedefi durumuna gelmiştir. Sonuçta Pol-Der yönetimi, kendilerine yönelik her olumsuz tavır ve davranışa karşı her türlü haberi üyelerinden almak ve kendilerine yönelik baskılara cevap verebilmek için yoğun olarak Pol-Der Gazetesi'ni kullanmaya başlamıştır. Diğer taraftan bu karşı duruş neticesinde Pol-Der Gazetesi sadece mesleki bilgi paylaşımı içeren bir gazete olmamış, Pol-Der şube veya temsilciliğinin bulunduğu her coğrafi alanda polis üst yönetimlerinin tarafsızlık ilkesine aykırı olarak yaptığı işlemler hakkında bir bilgi paylaşım noktası olmuştur.

\section{Pol-Der Gazetesinde örgütsel çatıșma izleri}

Pol-Der, ülke genelinde yayılmaya devam ederken ülkede hâkim olan siyasi zıtlaşmanın yarattığı toplumsal bölünme de açıktan açığa kendisini göstermiş, bu durum kendisini demokratik bir kitle örgütü olarak gören Pol-Der'in de gündeminde yer almıştır. Özellikle dönemin yöneticilerini polisin söz konusu ortamda siyasi etkilerden uzak, tarafsız bırakılması yönünde ikaz etmişlerdir. Bu ikaz da Pol-Der Gazetesi aracılığıyla yapılmıştır:

...Tüm kamu personeli açısından önem taşıyan tarafsılılk ilkesi Emniyet görevlileri açısından daha da hayati önem taşımaktadır. Çünkü emniyet hizmetlerinde çalışanlar diğer kamu personelinden farklı olarak kanunu temsil ederler. Kanun hâkimiyetini sağlarlar. Bu görevin gereği olarak da kendilerine zor kullanma yetkisi hatta silah kullanma yetkisi tanınmıştır. Bu yetkilerin tarafsızlıktan uzak olarak kullanılması tamiri mümkün olmayan neticeler doğurur. Polis halk bütünleşmesini engeller. Halkın polise olan güveni kaybolur. Teşkilata saygınlığını yitirir.

Bu bakımdan bireysel veya toplumsal adli olaylarda, siyasal amaçlı olaylarda polis yalnızca yasaların emrettiği tedbirleri almalı ve işlemleri yapmalıdırlar. $\mathrm{Bu}$ arada hükümetin gerekli gördüğü tedbirleri yerine getirmekle de yükümlüdür. $\mathrm{Bu}$, görevlilerin, siyasi iktidarın her türlü emir ve davranışlarına karşı boyun eğ-

1 Çalışmada yer alan alıntılar Pol-Der gazetesinden yapılmış ve belirtilen konuyla doğrudan ilgili olması nedeniyle seçilmişlerdir. 
meleri anlamına gelmemelidir. Anayasamızın kabul ettiği hukuk düzeni içerisinde siyasal iktidarın emirleri de yerine getirilmeyebilir (bkz. Anayasa Mad. 125) (Ulusoy 1975, s.1).

Kendilerini hizmet ettikleri halkın haricinde hiçbir güce ait hissetmeyen polislerin kurduğu Pol-Der'in tüm üyeleri, kendilerini "halkın polisi” olarak nitelemekteydiler (Öner 2003, s.35-76). Pol-Der'in genel başkanı olan Kazım Ulusoy'un yukarıdaki yazısı ise bunun en belirgin ifadesi idi. Pol-Der yönetimi kendisinden önce hiçbir meslek örgütü tarafından bu derece eleştiriye tabi tutulmayan polis örgütünün kendileri hakkında olumlu düşünmeyeceklerinin de bilincindeydiler. Onlar için öncelikli olan üyesi oldukları polis örgütünün ve meslektaşlarının menfaatleriydi:

Sayın Üye,

Derneğimizin faaliyetlerine duyduğunuz ilgiyi ve dernekleşmenin bilincine vararak yazmış olduğunuz mektupların değerlendirilme ve araştırılmasının yapılacağını, konulara süratle eğilineceğini, ayrıca durumdan fazla gurur ve haz duyulduğunu dernek yöneticileriniz adına saygılarla bildirir, alakalarınızın devamını dileriz.

Konuya baştan değinilmek istenirse; çağımızda, dernekler, yöneticilerimizin birer ölçüsüdür. Oysa dernekler, çağ ve insanlık ölçüleri dışındaki yönetimleri sonunda doğmak zorunluluğunu duymuşlardır. İyi bir idare personeli dernekleşmeye itmez, bu uğraşa da gerek kalmazdı.

Dernekler, kuruluşlarının ilk yıllarında elbette fazlasıyla baskı altında kalacak, yöneticiler hatalarını yüzlerine vuranlarının faaliyetlerini istemeyecek, sicil, tayin gibi hususlarla onları tehdit edeceklerdir.

Neticede, yeni kurulmuş olan derneğimizi hem kuruluş çalışmasını tamamlamak hem de üyelerini inandırma ve bilinçlendirmek için zorunlu olarak bir bocalama geçirecekti. Bunun nedenlerini yukarıda göstermiş̧tik. Bütün bunlara rağmen sadece kuruluş çalışması mı? yapmalıyız.

Açıkça söylemekten gurur duyarız ki derneğimizin faal bir yönetici kadrosu var. Gayemiz üye toplamak değildir. Propaganda yapmak ve derneğe menfaat sağlamak değildir. Bizim camiamızda birden fazla dernek vardır. Gayeleri ayrıdır. Her arkadaşımız istediği derneğe üye olabilir. Yeter ki dernekleşmenin ne olduğunu bilelim. Çağın gerçeği olarak bunun zorluğunun bilincine varalım. İşte amacımız buradadır...(Pol-Der 1975b, s.4). 
Pol-Der, o ana kadar olmayan bir şeyi yapmaya çalışmakla, yaşanan örgütsel ve toplumsal çalkantı ve çatışmalara rağmen ülke genelinde çalışan polisler arasında hayli popüler hale gelmiştir. Fakat yukarıda alıntılanan PolDer yönetiminin ön görüsünde olduğu gibi, polislerin bu tür bir meslek örgütüne sahip olmasına ve kendilerine aykırı gelen birçok konuyu kamuoyu ile paylaşmasına tahammülü olmayan yönetim tarafından yayılma sürecinde de engel olunmak istenmiştir:

...Pol-Der merkezinin faaliyetlerini benimseyen, Trabzon ilinde görevli arkadaşlarımızın şube açma istekleri üzerine, gerekli yetki verilmiş, formalite tamamlanmış, vilayet makamına müracaat ile şube açma işlemi hukuken tamamlanmış iken sayın il emniyet müdürü tarafından makama çağrılan geçici yönetim kurulunun tokatlandığı, keza huzurda der edildiği ve işlem dosyasının heyete iade edilerek şubemizi açtırmayacağını ifade ettiği ve bilahare üç geçici yöneticinin çalışmalarının devamını önlemek için bölücü faaliyet gösterdikleri gerekçesi ile il belediye hudutları dışına atandıkları noter huzurunda verilen ifadelerden anlaşılmıştır...(Pol-Der 1976a, s.1).

Pol-Der yönetimi ile Polis Örgütü üst yönetimi arasında yaşanan örgütsel çatışma Pol-Der Genel Başkanı Kazım Ulusoy ile IPA Türkiye Şubesi Başkanı Muzaffer Özbayrak'ın Bakanlık emrine alınmaları ile sonuçlanmıştır. Yönetimin bu tür bir yola başvurmasının gerekçesi olarak her iki yöneticinin Günaydın gazetesine verdikleri "parti militanları başımıza getirilmezse olaylar önlenebilir" ve "hükümetin emri ile polis halka silah çekemez" başlıklı açıklamaları gösterilmiştir (Pol-Der 1976b, s.1). Oysaki açılamaların içeriğine bakıldığında her iki meslek örgütü yöneticisinin de polis örgütüne siyasi kimliklerinin gölgesinde giren kişilere karşı oldukları ve polislerin, siyasilerin hukuki olmayan emirlerinden çok yasaları uygulamaları gerektiğini, ülkede artmaya başlayan toplumsal olayların, devletin tarafsızlı̆̆ı sağlaması ile geçekleşebileceğini belirttikleri anlaşılmaktadır. Pol-Der Gazetesi'nin 1976 Haziran sayısında bir takım belgelere yer veren Pol-Der yönetimi polis örgütünün menfaatlerini-özellikle tarafsızlığını- neden sağlamaya çalıştıklarını ve bunun delillerini ortaya koymak istemişlerdir:

Sayın Meslektaşlarım,

Dernek Merkez Yönetim Kurulu olarak görev üstlendiğimizden bu yana bir takım şeyler yapmaya çalıştığımızı duydunuz, okudunuz veya izlediniz.

Olumlu veya olumsuz, akıllıca-delice, zamanlı-zamansız yapıldığı iddia edilen bu girişimlerimizin nedenlerini ve içyüzlerini açılamak gereğini duyduk. 
Bu sayıda sunmaya çalıştı̆̆ımız belge ve yazıları dikkatle incelemek lütfunda bulunursanız, bizleri daha gerçekçi olarak tanımak ve görevimizi yapıp yapmadığımız konusunda daha objektif fikir edinmek olanağını bulacağınıza inanıyoruz (Ulusoy 1976, s.1).

Pol-Der yönetimi, polislik mesleğinin ana ilkesi olan tarafsızlı̆̆ın üzerinde yoğun olarak durmasına rağmen polis örgütünün üst yönetimi tarafından bu görüşe kulak tıkanması 5. Olağan Genel Kurul'da kabul edilen bildiri ile eleştirilmiştir. Bu eleştiri, Pol-Der Gazetesi'nin 1976 Ağustos baskısında yayınlanan bildirinin son bölümünde açıkça ifade edilmiştir:

...Türk Polisi hiçbir şart altında siyaset adamlarının, hiçbir hükümetin ve makamın yasalara aykırı eylemlerine alet olmayacak Atatürk devrimlerinden, ilkelerinden ayrilmayacaktır.

Netice olarak Türk Polisinin yasalar çerçevesinde Türk milletinin yanında ve hizmetinde olacağını kamuoyuna saygı ile duyururuz (Pol-Der 1976c, s.1).

Pol-Der ve IPA Türkiye Şubesi ile Polens derneklerinin, polis örgütünün tarafsızlığının sağlanması ve belirli bir parti düşüncesini paylaşan kişilerin özellikle polis olmak üzere polis örgütü kadrolarına alınması ile meydana gelecek kadrolaşmayı önlemek amacıyla yaptıkları itirazlar Pol-Der Gazetesi üzerinden devam ederken, Pol-Der Genel Başkanı Kazım Ulusoy geçici olarak Ankara'dan Niğde'ye tayin edilmiştir. Bu duruma da tepki gösteren Pol-Der, Kazım Ulusoy'un konuyu yargıya taşıması neticesinde Danıştay tarafından verilen yürütmeyi durdurma kararını da 1976 Eylül baskısında yayınlamıştır (Pol-Der 1976d, s.1). Pol-Der Gazetesi'nde, polis örgütü yönetiminin Pol-Der üyelerine yapılan görevden uzaklaştırma, atama veya pasif görevlere getirme konularını içeren yazılar yazılmaya devam etmiştir:

...Değerli arkadaşlarım, Pol-Der'in gayesi Atatürk devrimlerine bağlı kalmak koşulu ile tüm siyasi baskılara, memur kıyımına ve partizanca atamalara boyun eğmemektir. Pol-Der'in gayesi siyasi etki altında kalmadan vatandaşlar arasında siyasi düşüncelerinden dolayı ayrım yapmadan görev yapmaktır. Pol-Der'in gayesi Atatürkçülük ve devrimlere saygılı olmak şartı ile kaba kuvvete karşı birlik ve beraberlik içerisinde mücadele etmektir (Güngör 1976, s.2).

Pol-Der'e göre, 1970'lerin ortalarından itibaren başlayan toplumsal çatışmanın çözümü polislerin tarafsız olmalarına bağlıydı fakat Pol-Der, polis üst yönetiminin bu davranışı yeterince gösterdiğine inanmıyordu. Bunun bir göstergesi olarak kabul ettikleri personel atama kriterleri bu nedenle nükteli bir şekilde eleştiriye tabi tutulmuştur: 
- Polis Enstitüsü Müdürlügü̈nü elde edebilmek için ülkemizdeki siyasi partilerden birinden (!) milletvekili olarak adaylığınızı koyup ön seçimlerde liste sonuncusu olmak gereklidir.

- Ön seçimlerde yaptığınız masrafları kısa zamanda tasarruf edebileceğiniz yüksek dereceli kadrolar tercihinize sunulduğunda da Polis Enstitüsü Müdürü olmak istediğinizi söyler ve olursunuz.

- Enstitüye Müdür olduktan sonra da mesleğin orta ve bazen de yüksek mevkilerine yönetici yetiştiren bu eğitim kurumunu çağımızın teknolojisinden yararlanarak kriminal alanda araştırma yapan, bilimsel laboratuarları olan, ihtisaslaşmaya yönelik, her mezunu bir lisan bilen, temel hak ve özgürlüklere saygılı, modern polis yöntemlerini öğreten, akademik kariyeri olan öğretim görevlilerimizin ders verdiği, mesleğin en yüksek mevkilerine yönetici yetiştiren bir kurum haline getirme gayretleri içine girmemeye çalıştığınız sürece en az dört sene ve daha fazla müdürlük yapma olanağınız vardır....

- Milletvekilliğine adaylığınızı koyduğunuz siyasal parti görüşünde polis amiri yetiştirdiğinizden valilik teklif ediliyor şeklinde propaganda yaptırarak değerinizi bir kat daha artırınız. Ve valiliğe atanma kararnamenizi bekleyiniz. Kim bilir belki olursunuz...(Pol-Der 1976e, s.1).

Pol-Der'in polisin tarafsız olmasıyla ilgili olarak polis üst yönetimine yönelik eleştirel bakış açısı yönetimin belirli bir zaman sonra elindeki "tayin" kozunu oynamasına neden olmuş ve birçok personelin vaktinden önce yerlerinin değiştirilmesine başlanmıştır. Zamansız yapılan bu tayin furyası neticesinde birçok Pol-Der üyesi, manevi olduğu kadar maddi olarak da mağdur olmuş, onların bu mağduriyetlerini gidermek için yine Pol-Der Gazetesi vasıtasıyla yardım kampanyası düzenlenmiştir:

POLİ'in tarafsızlığını sağlamak, halkla bütünleştirmek ve tüm üyelerinin demokratik haklarını geliştirmek amacında olan Örgütümüz,

POL-DER

(Polis Derneği)

- Kıyılan Pol-Der üyelerine Yardım Kampanyası-adı altında bir sosyal yardım kampanyası açmış bulunmaktadır.Katılmak isteyenler bağışlarını......Bankası..... nolu hesabımıza yatırabilirler.

Haklı mücadelemize maddi ve manevi destekleri ile katkıda bulunan Örgüt üyelerimize, demokratik kuruluşlara ve tüm halkımıza bu vesile ile bir kere daha teşekkürü borç biliriz. 
Saygilarımızla.

POL-DER

(Polis Derneği)

Genel Merkezi (Pol-Der 1977, s.1).

Polis Örgütü'nün üst yönetimi tarafından Pol-Der üyelerine yapılan muameleler tayin, pasif göreve atama vb. işlemlerle kalmamakta, bir takım özlük haklarını elde etmelerine de engel olunmaktaydı:

Ben Eskişehir vilayetinde 4948 üye nolu Ali Rıza Gökçen, toplum polisiyim. Bu satırlarımda kendimin mağdur kaldığım için haksızlıklardan bahsetmek istiyorum. Örneği Eskişehir İktisadi ve İdari Bilimler Akademisinde görevli bir şahsı darp ettiğim iddiasıyla hiçbir adli işlem yapılmadan 2 ay açıkta kaldım. Ve bu açıkta kaldığım ayların, vazifeye başladığım 28 Şubat 1977 gününden bu tarafa diğer farklarını alamadım. Alacağımız da meçhulmüş.

1. İkinci bir husus sebepsiz yere ifadem dahi alınmadan bazı suçlamalardan örnek. "Ev sahibin ve arkadaşlarınla iyi geçinmemekten" resen üç yevmiye kesmek. Tabii emniyet müdürü kesiyor. Tamamen asılsız çünkü ev sahibi kodaman adam ben de Pol-Derliyim. Arkadaşlarla geçinmemek yine bundan dolayıdır.

2. İzin alıp ayrıldığım dairemden vazifeye gelmedi diye ifadem alınmadan Emniyet Müdürü tarafından resen üç maaş katı kesim.

3. Vazifeye sevk eden amir resmen tahrik etmek için 3 arkadaşa küfür ediyor. Ben de dahil nöbetçi müdürlüğüne durumu bildiriyoruz. 3 arkadaş ilgilenmiyor biz de daha sonra durumu Vali'ye izah ediyoruz. Resen ihtar, resen 3 yevmiye... Tabi Emniyet Müdürü yapıyor. İfademiz dahi alınmadan.

Bunlar yetmiyor gibi devamlı 3. Şube Müdürü Mustafa İnan tarafından derneli olduğum için baskılar gördüm.

Bütün bu anlatmak istediklerimi Pol-Der Gazetesi'nde yayınlamanızı istirham ediyorum. Çünkü şu an tayinim Ağrı ili Emniyet Müdürlüğüne çıktı. Bu zamana kadar sabrettim fakat bugün her şeyi yazmayı yararlı gördüm.

Emin olun bunla bizi yıldırmaz yeter ki bu durumlar kamuoyunda aydınlatılsin...(Gökçen 1977, s.2).

Bu durumun bir adım ilerisi ise toplumda olduğu gibi polis örgütü içerisinde de "sağc1" ve "solcu" etiketlenmesi yapılmaya başlanmasıdır. Bu ayrımda Pol-Der üyesi polisler açıkça "solcu" olarak nitelenmeye başlanmış, bu ayrımın açık bir şekilde mağduru olan üyeler kendi başlarına gelenleri 
Pol-Der Gazetesi'ne göndermiş, bu yakarışları içeren mektuplar da gazetede yayımlanmaya çalışılmıştır:

...Karakolda eşit muamele yapmamıza karşın beni ve arkadaşım Dilaver Ağıral'ı sürekli, Valimiz M. Zeki Demirkan'a şikâyet ediyorlar. Asılsız suçlamalara hedef oluyorduk.(...) Şikayetim bu da değil.

Lise mezunuyum. Mesleğime ve bulunduğum topluma daha yararlı olabilmem için Emniyet Genel Müdürlüğümüzce açllan kurslara dilekçeler vermiştim. Kursa katılma koşullarına uymaktayım. Narkotik Kursunu 15.5 puan alarak katılma hakkını kazandığımı öğrendim. Ve 11.11.1977 günlü ve 257836 telsiz sayılı ile İçişleri Bakanlığı Ordu Valiliğine "narkotik kursuna katılmak üzere yazının tebliği ve Ankara Yusuf Kahraman Polis Okulunda açılacak bir aylık kursa katılmam için 5 Aralık 1977' de Ankara'da olmamın" gerektiğini bildirdikleri halde bu emir bana tebliğ edilmediği gibi Sayın Valimiz Bakanlığa cevap olarak "Bu polis memuru solcudur. Narkotik kursuna katılması sakıncalıdır" diye yazı gönderince bu kurs hakkımı kaybettim. (...) Kaybolan bu haklarımı geri almak için ancak Derneğimize başvuruyorum.

Bu Vali ile bu Vali gibi yanlı davrananları kime, kimlere şikâyet ederek cezaland1rılmalarını isteyelim? (Polis Memuru 1978, s.2).

1978 yılı ideolojik, etnik ve mezhepsel ayrımın toplumu açıça bölmeye başladığ1 ve bu bölünmüşlüğün devletin kurumlarında da yer etmeye başladığı yıldır. Polis örgütü ise toplumla en yakın şekilde ilişkide olması nedeniyle bu bölünmüşlük furyasından payına düşeni almıştır. Özellikle diğer devlet kurumlarında olduğu gibi örgüt içerisinde "sağcl" olarak bilinen polislerin de kendilerini ideolojik açıdan savunacak Polis Birliği Derneğini (Pol-Bir) 23 Şubat 1978' de kurmaları ile polis içindeki ayrışma tescillenmiştir (Şimşek 2015, s.306). Çalışmanın ilk satırlarında da belirtildiği üzere Pol-Bir, Pol-Der yönetimini kabul etmeyen, onlardan çok farklı dünya görüşüne sahip polisler tarafından kendilerine Pol-Der yönetiminde yer verilmemesi nedeniyle PolDer'e karşı olarak kurulmuş bir meslek örgütüydü. Pol-Bir'in ortaya çıkışı, Pol-Der'e, polis örgütü yöneticilerinin yanında ikinci bir cephe açmıştır denilebilir.

1978 yılı, Pol-Der Gazetesi'nin de son sayısının yayınlandığı yıldır. Özellikle bu dönem yayınlanan sayıya bakıldığında gazetenin ilk çıktığı düşüncenin aksine daha fazla "sol" düşünceyi içeren yazıların yazıldığı dikkati çekmektedir. Bu dönem yayınlanan Pol-Der Gazetesi'ndeki manşetler arasında "Baskılara Karşı Direnelim” , "İşçi Sınıfının Nihai Hedefi”, "Faşizm Kavramı 
Üzerine" , "Ekonomide Temel Kavramlar" , "Ekonomik Temel ve Üst Yapı" gibi ifadeler yer almaktadır (Eylül 1978). Bu durumu kendisini ifade ederken anlaşılamayan ve kendisine karşı fikirde yer aramaya çalışan polislerin arayışlarının son durağı olarak değerlendirmek yanlış olmayacaktır. Yine bu yıl içinde Ankara Genel Merkez ve Şubesi'ne yapılan saldırılar, İstanbul'da PolDerli bir grup polisin yine sol düşünceli kişilerle beraber afiş asma girişimleri, kimi yerlerde sağcı ve solcu polislerin görev yerlerinde birbirleri ile çatı̧̧maları veya silahla birbirlerini vurmaları Pol-Der'i yıpratmış ve tüm bunlara ek olarak son dönemde örgüt içerisindeki yönetsel istikrarsızlıklar Pol-Der Gazetesi'nin kimi zaman yayınlanamamasına neden olmuştur. Sonuçta 26 Ocak 1979 tarihinde de Pol-Der ile birlikte tüm polis dernekleri kapatılarak polisin mesleki olarak örgütlenmesi yolundaki tüm imkânlar kaldırılmıştır.

\section{Sonuç}

İnsan hareketlerini belirleyen temel unsurlar güdüler, değerler, ihtiyaçlar vb.dir. İnsanlar bu unsurlara göre gösterdikleri hareketler neticesinde örgütleri meydana getirmekte yine bu örgütler içinde aynı insani davranışları göstermektedirler. Örgütlerin yapısallığında bulunan başka bir unsur ise insanların davranışlarının birer sonucu olan birbirleri arasındaki ilişkilerdir. Bir ilişkiler yumağı olarak da nitelendirilebilecek örgütlerde, yöneten ve yönetenler arasındaki ilişkiler her zaman istenildiği gibi seyretmeyebilmektedir. Her iki tarafın da kendilerine özgü değerleri, ihtiyaçları ve güdüleri bulunmaktadır. İşte bu unsurlar arasında farklılıkların oluşması örgüt içerisinde çatışmaya ortam hazırlamaktadır. Çatışma bir anda olmamakta, belirli safhaları bulunmaktadır. Haberdar olma, iletişim ve direnme sonucunda meydana gelen çatı̧̧ma başlı başına bir süreçtir. Bu süreç içerisindeki her unsur yine insanların birbirlerine karşı gösterdikleri tavır ve davranışları içermektedir. Çatışmanın iletişim unsurunda yukarı ve aşağıya doğru iletişimde kullanılan yazılı ve sözlü uygulamaların her iki taraf için farklı nitelikleri bulunmaktadır. Örgütün başat ilkelerinden biri olan yöneten ve yönetilen ayrımında meydana gelen çatışmalarda özellikle yönetilenler, çatışmanın son safhası olan direnme noktasında birlik ve beraberliklerini sağlamak suretiyle belirli örgütler oluşturmaktadırlar. İşte bu örgütler, örgütsel veya mesleki olan sorunlarını dile getirmek amacıyla kolektifliğin yanı sıra genel olarak yazılı yolları tercih etmektedirler. 1970 yılında kurulan Polis Derneği, 17 Mayıs 1975 tarihinde Pol-Der olarak yeniden doğduğunda polis örgütü yönetimine karşı sözlü yerine yazılı yollarla ulaşmayı tercih etmiştir. Çok kısa bir sürede birçok üye kaydeden dernek yönetimi, özellikle Pol-Der Gazetesi ile mesleki bilgi 
paylaşımının yanı sıra hem yönetime istek ve görüşlerini bildirmeye çalışmış hem de üyeleri ile ilişki kurmuştur. Yoğun olarak toplumsal ayrışmaya doğru gidilen 1975 sonrası ortamda tek çarenin devlet hizmeti yürüten polislik mesleğinin ve polislerin tarafsızlığı olduğu görüşünü paylaşan Pol-Der yönetimi, çeşitli kadrolaşma hareketleri yaparak bu tarafsızlığa aykırı hareket ettiğini düşündüğü dönemin siyasetçileri ile polis örgütü yönetim ve yöneticilerini eleştiriye tabi tutmuştur. Pol-Der yönetiminin ve üyelerinin yaptıkları eleştirilerin beşiği ise Pol-Der Gazetesi olmuştur. Pol-Der yönetimi ve üyeleri polis örgütü üst yönetimine dilek ve şikâyetlerini Pol-Der Gazetesi ile iletmeye çalışmışlar, sonuçta da tüm kapılar kendilerine kapatılmıştır. Disiplin mesleği olarak örgüt haricinde başka bir meslek örgütlenmesini kabul etmek istemeyen polis örgütü yönetimi kendilerine yapılan eleştirilere Pol-Der yönetici ve üyelerine yönelik disiplin cezaları, pasif görevlere atama ve zamansız tayinler ile cevap vermiştir. Bu çatışmanın sonucunda Pol-Der, o dönem kendisi ile beraber hareket eden IPA Türkiye Şubesi, Polens ve Pol-Der'e karşı sağ görüşlü polislerin oluşturduğu Pol-Bir gibi diğer derneklerle birlikte kapatılmıştır. Polis Meslek Örgütleri'nin kapatıldığı tarihten başlamak üzere günümüz de dâhil olmak üzere polislerin örgütlenmeleri yasaklanmıştır. 


\section{Kaynakça}

Amacımız üyelere hizmet etmektir (1975b) Pol-Der, Ekim, s.4

Ankara valisi Pol-Der ve Pol-Bir genel merkezlerini kapattı (1978) Cumhuriyet, Temmuz, s.1.

ASLAN, O. E. (2005) Kamu personel rejimi: statü hukukundan esnekliğe. Ankara: Türkiye Ortadoğu Amme İdaresi Yayını.

BİROL, D. (1975) Kıvançliyız. Pol-Der, Ekim, s.1

BORMANN, E. G. vd. (1969) Interpersonal communication in the modern organization. USA: Prentice-Hall, Inc.

POLİS MEMURU (1978) Bu polis memuru solcudur?. Pol-Der, Ocak-Şubat, s.2.

Danıştaydan bir karar (1976d) Pol-Der, Eylül, s.1.

Danıştayın en son kararı (1975a) Pol-Der, Ekim, s.1.

Derneklere baskı arttı (1976b) Pol-Der, Mayıs, s.1.

Duyuru (1977) Pol-Der, Eylül, s.1.

Dün yapılan MSP gençlik kolları kongresinde Erbakan'a Necmeddun-i Türkiye diye bağırıldı (1975) Barış, 30 Mayıs, s.1.

EISENBERG, E. M. ve GOODALL, H. L. (2004) Organizational communication: balancing creativity and constraint. USA: Bedford/St. Martin's Publishing.

ERKAN, Ü. (1974) Polisi polis yönetecek. Polens Dergisi, 8, s.3.

Eskişehir şubemiz kuruldu (1975) Pol-Der, Kasım, s.3.

FLEMING, P. ve SPICER, A. (2007) Contesting the corporation: struggle, power and resistence in organizations. USA: Cambridge University Press.

GIBBS, J. R. (1943) Defensive communication, TUBBS, S. L. ve CARTER, R. M. (der.) içinde. Shared Experiences In Human Communication. New Jersey: Hayden Book Company, s.44-49

GÖKÇEN, A. R. (1977) Pol-Der genel merkezine. Pol-Der, Eylül, s.2.

GÜLMEZ, M. (1996) Dünyada memurlar ve sendikal haklar. Ankara: Türkiye ve Ortadoğu Amme İdaresi Enstitüsü Yayını.

GÜNGÖR, K. (1976) Pol-Der'in kuruluş ve amacı. Pol-Der, Eylül, s.2.

HEUSSER, A. (1958) Employee publications. REDFIELD, C. E. (der.) içinde. Communication in management: the theory and practice of administrative communication. USA: The University of Chicago Press, s.131-148. 
HODSON, R. (1995) Worker resistence: an underdeveloped concept of sociology of work. Economic and Industrial Democracy, 16(1), s.79-110.

İzmir'de de bir şubemiz açlddı (1975) Pol-Der, Kasım, s.3.

JERMIER, J., KNIGHTS, D. ve NORD, W. (1997) Resistance and power in organizations. USA: Routledge Publications.

KOÇ, Y. (2010) Türkiye işçi sınıfı tarihi: Osmanlı'dan 2010'a. Ankara: Epos Yayınları.

KINICKI, A. ve FUGATE, M. (2003) Organizational behavior: key concepts, skills and best practises. USA: McGraw-Hill Publications.

LUTHANS, F. (1989) Organizational behavior. USA: McGraw-Hill Publications

MARTIN, J. ve FELLENZ, M. (2010) Organizational behaviour and management. United Kingdom: Cengage Learning EMEA.

METCALF, H. C. ve URWICK, L. (2003) Dynamic administration: the collected papers of Mary Parker Follett. USA: Routledge Publishing.

ÖNER, S. (2003) Halkın polisi: Pol-Der anıları. İstanbul: İletişim Yayınları

Polis Derneği genel kurul bildirisi (1976c) Pol-Der, Temmuz, s. 1.

Polis Enstitüsü nasıl yönetilir? (1976e) Pol-Der, Ekim, s.1.

PUTNAM, L. L. ve POOLE, M. S. (1987) Conflict and negociation. JABLIN, F. M.

(der.) içinde. Handbook of organizational communication. USA: Sage Publications, s.549-599.

REBER, R.W. ve TERRY, G. A. (1975) Behavioral insights for supervision. USA: PrenticeHall Inc.

REECE, B. L. ve BRANDT, R. (1999) Effective human relations in organizations. USA: Houghton Mifflin Company.

RICHMOND, V. A., McCROSKEY, J. C. ve McCROSKEY L. L. (2005) Organizational communication for survival: making work, work. USA: Pearson Education Inc.

ROBBINS, S. P. ve JUDGE, T. A. (2013) Organizational behavior. USA: Pearson Educations Inc.

Sayın Kemal Serhadlı Trabzon şubemizi açtırmadı (1976a) Pol-Der, Ocak, s.1.

ŞİMŞEK, S. (2015) Polislik kurumunun inşası ve polislerin meslek örgütlenmesi: Türkiye, Ingiltere ve Fransa örnekleri. Yayımlanmamış Tez (Doktora). Türkiye ve Ortadoğu Amme İdaresi Enstitüsü.

T.C. Anayasası (1961) [Çevrimiçi]. http://www.tbmm.gov.tr/anayasa/anayasa61.htm. [Erişim Tarihi: 11.10.2015]. 
$154<$ ilef dergisi

THAYER, L.O. (1961) Administrative communication. USA: Richard D. Irwin, Inc.

ULUSOY, K. (1975) Emniyet görevlilerinin siyasal tarafsızlı̆̆ı. Pol-Der, Aralık, s.1. ULUSOY, K. (1976) Bu say1. Pol-Der, Haziran, s.1. 